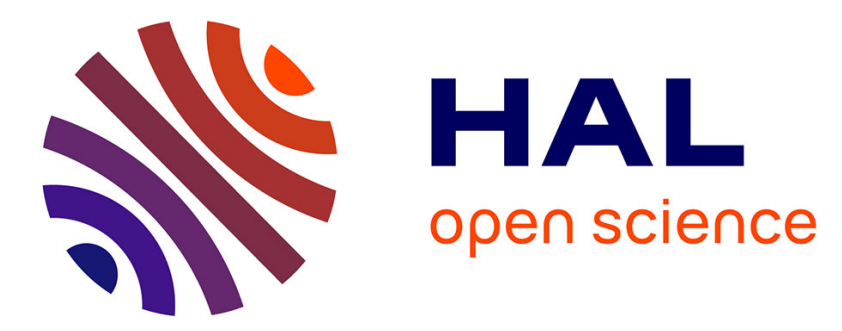

\title{
Surface performances of PVD ZrN coatings in biological environments
}

\author{
Chams Eddine Ramoul, Nasser Eddine Beliardouh, R. Bahi, Corinne \\ Nouveau, Abdelghani Djahoudi, Michael J. Walock
}

\section{To cite this version:}

Chams Eddine Ramoul, Nasser Eddine Beliardouh, R. Bahi, Corinne Nouveau, Abdelghani Djahoudi, et al.. Surface performances of PVD ZrN coatings in biological environments. Tribology - Materials, Surfaces \& Interfaces, 2018, 13 (1), pp.12-19. 10.1080/17515831.2018.1553820 . hal-03066513

\section{HAL Id: hal-03066513 https://hal.science/hal-03066513}

Submitted on 15 Dec 2020

HAL is a multi-disciplinary open access archive for the deposit and dissemination of scientific research documents, whether they are published or not. The documents may come from teaching and research institutions in France or abroad, or from public or private research centers.
L'archive ouverte pluridisciplinaire HAL, est destinée au dépôt et à la diffusion de documents scientifiques de niveau recherche, publiés ou non, émanant des établissements d'enseignement et de recherche français ou étrangers, des laboratoires publics ou privés. 


\title{
Surface performances of PVD ZrN coatings in biological environments
}

\author{
C. Ramoul (1) a,b, N. E. Beliardouh ${ }^{a}$, R. Bahi ${ }^{a}$, C. Nouveau (1) ${ }^{c}$, A. Djahoudi ${ }^{d}$ and Michael J. Walock

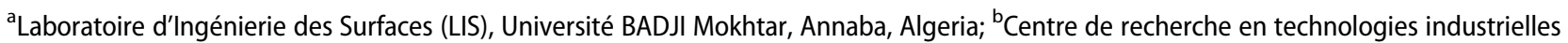 \\ CRTI, Cheraga, Algérie; 'Arts et Métiers ParisTech, Laboratoire Bourguignon des Matériaux et Procédés (LaBoMaP), Cluny, France; \\ dLaboratoire de microbiologie, Université BADJI Mokhtar, Annaba, Algérie; ${ }^{~}$ Vehicle Technology Directorate, U.S. Army Research Laboratory, \\ Aberdeen, MD, USA
}

ABSTRACT

Zirconium nitride ( $\mathrm{ZrN})$ thin films were deposited by reactive RF magnetron sputtering on Ti$6 \mathrm{Al}-4 \mathrm{~V}$ and $\mathrm{Si}(100)$ substrates for potential use in biomedical applications. The tribological behaviour was evaluated against bovine bone in dry condition using a pin-on-disc apparatus. Abrasion is the primary wear mechanism observed in $\mathrm{ZrN} /$ bone contact. The corrosion properties were determined through two electrochemical techniques: potentiodynamic polarization and electrochemical impedance spectroscopy. The coatings with reduced oxygen content provided: (i) good resistance against corrosion when exposed to physiological solution and (ii) better anti-bioadhesion against Staphylococcus aureus bacteria.

\section{KEYWORDS}

PVD coating; ZrN; wear; corrosion; bioadhesion

\section{Introduction}

In the field of orthopaedic implants, the challenge is to develop alloys with high biocompatibility and the requisite material properties to effective serve as substitute bones and joints for a long period without rejection. Here, bone-implant integration is closely related to the biocompatibility (immunology/bioadhesion), wear and corrosion behaviour of both the implant (artificial organ) and surrounding bone tissue.

Transition metal nitrides, oxides and intermetallics, especially Titanium-based alloys, have been widely studied and show great potential for the protection of orthopaedic applications. Diffusion hardened $\mathrm{Zr}$ $2.5 \mathrm{Nb}$, known as ('Oxinium'), is another category of surface engineered material used for bio implants. As recently reviewed by Dearnley [1], it appears as the better non-coated material.

In order to eliminate the implant rejection risks due to bacterial infections, newer approaches are currently being evolved. The goal is to convert the surfaces of biomedical devices into antimicrobial surfaces while preserving the corrosion and wear resistance. Nanostructured surfaces and antimicrobial agents, such as silver, used to reduce infections are the best coating strategies and could represent an alternative to antibiotics.

Recently, it was demonstrated that bacterial adhesion on Zirconium alloy films was minimized by tailoring the surface with silver ions surrounded by amorphous carbon phases using a sputtering system [2]. Unfortunately, accumulation of silver ions $\left(\mathrm{Ag}^{+}\right)$ is well known to have negative effects on general health [3]. So, the challenge becomes the development of multifunctional surfaces with simultaneous opposite responses; on the one hand towards human cells, i.e. providing adhesion molecules for attaching tissues and cells (osseointegration) and against bacterial adhesion/proliferation (antibacterial activity) on the other hand.

Over the past two decades, $\mathrm{ZrN}$ coating has attracting interest for its excellent erosion resistance, biocompatibility, good ductility and excellent chemical stability [4]. In addition, there is evidence that $\mathrm{ZrN}$ coatings have better corrosion resistance than TiN coatings [5].

In this work, a $\mathrm{ZrN} / \mathrm{Zr}$ system was evaluated for its suitability as a protective coating in biological environments. The corrosion resistance in physiological solution (PS) and tribological performances against bovine bone were investigated systematically. This was followed by a study of the material's antibacterial activity against Staphylococcus aureus (S. aureus).

This study was conducted taken into account two fundamental aspects (i) an economic aspect, i.e. a low-cost biomaterial and (ii) an environmental aspect; because recovering (recycling) only one metallic element ( $\mathrm{Zr}$ ) from an oxide is much easier than recovering two metallic elements or more from a complex structure.

\section{Experimental}

\subsection{Coatings deposition}

Zirconium Nitride films were realized by the radio frequency magnetron sputtering technique (NORDIKO 
type 3500). A pure Zirconium (99.98\%) disc (101.6 mm diameter, $3 \mathrm{~mm}$ thick) was used as the target material. The substrates are Titanium alloys (Ti-6Al-4V) intended for tribological tests and $\mathrm{Si}$ (100) wafers $\left(10 \times 10 \times 0.380 \mathrm{~mm}^{3}\right)$ for corrosion and biological tests.

Metallic substrates (cylinder $\varnothing=20 \mathrm{~mm} \times 4 \mathrm{~mm}$ ) were polished by $\mathrm{SiC}$ papers grade 800 . All substrates were ultrasonically cleaned for $15 \mathrm{~min}$ in acetone and dried in air. Before deposition, the target disc and the substrates were in situ etched for $5 \mathrm{~min}$ at $10 \mu \mathrm{bar}$ in an Ar discharge. A pure $\mathrm{Zr}$ buffer layer of approximately $100 \mathrm{~nm}$ was first deposited ( $10 \mathrm{~min}, 5 \mu \mathrm{bar}$ ) to improve adhesion between the $\mathrm{ZrN}$ topcoat and the substrates. The target to substrate distance was fixed at $80 \mathrm{~mm}$ and the target bias voltage was $-900 \mathrm{~V}(\mathrm{Zr})$.

In addition to improve the adhesion, a functional buffer layer is an efficient strategy for overcoming corrosion substrate problems (contact between the electrolyte and the substrates surface because of pores and other coating defects) and improving the tribological properties. Four (4) samples (ZrN-01; ZrN-02; $\mathrm{ZrN}-03$ and $\mathrm{ZrN}-04)$ were deposited by changing $\mathrm{Ar} /$ $\left(\mathrm{N}_{2}+\mathrm{O}_{2}\right)$ ratio, as summarized in Table 1. The total working pressure $(5 \mu \mathrm{bar})$, deposition time $(\sim 242 \mathrm{~min})$ and substrate temperature $\left(150^{\circ} \mathrm{C}\right)$ were kept constant. As-deposited and post-test films were characterized by the scanning electron microscopy (SEM; JEOL JSM-5900LV-10 kV) with energy dispersive X-ray spectroscopy (EDS; Oxford INCA $x$-act) and optical profilometry (Veeco-Wyko NT1100).

\subsubsection{Bone pins preparation}

The bone pins were prepared from the femur of a bovine. The complete femur was immersed in distilled water at a constant temperature $\left(100^{\circ} \mathrm{C}\right)$ for $2 \mathrm{~h}$ to remove residual soft tissue attached to the bone. From this clean bone, the pins were machined as cylinders (cylinder $\varnothing=6 \mathrm{~mm} \times 20 \mathrm{~mm}$ ), ultrasonically cleaned $(15 \mathrm{~min})$ in acetone, dried in air and finally kept at $3-4^{\circ} \mathrm{C}$ in a fridge (until ready for use in the pin-on-disc tribometer).

\subsection{Coating characterizations}

\subsubsection{Tribology}

Dry friction tests were conducted in ambient air at room temperature and relative humidity of $40 \% \pm 5$

Table 1. Chemical composition and roughness of $\mathrm{ZrN} / \mathrm{Zr}$ coatings.

\begin{tabular}{|c|c|c|c|c|c|c|c|}
\hline \multirow[b]{2}{*}{ Sample } & \multirow{2}{*}{$\begin{array}{c}\text { Ratio } \\
\mathrm{Ar} /\left(\mathrm{N}+\mathrm{O}_{2}\right) \\
(\%)\end{array}$} & \multirow{2}{*}{$\begin{array}{l}\text { Total } \\
\text { thickness } \\
(\mu \mathrm{m})\end{array}$} & \multicolumn{3}{|c|}{$\begin{array}{l}\text { Chemical } \\
\text { composition } \\
\text { (Weight \%) }\end{array}$} & \multicolumn{2}{|c|}{$\begin{array}{l}\text { Roughness } \\
(\mu \mathrm{m})\end{array}$} \\
\hline & & & $\mathrm{N}$ & 0 & $\mathrm{Zr}$ & $R_{\mathrm{a}}$ & $R_{\mathrm{q}}$ \\
\hline $\mathrm{ZrN}-01$ & $80 / 20$ & 1.82 & 16.5 & 1.5 & 81.9 & 0.024 & 0.031 \\
\hline $\mathrm{ZrN}-02$ & $70 / 30$ & 1.67 & 16.4 & 1.8 & 81.8 & 0.027 & 0.053 \\
\hline $\mathrm{ZrN}-03$ & $60 / 40$ & 1.75 & 12.2 & 4.9 & 82.9 & 0.018 & 0.024 \\
\hline $\mathrm{ZrN}-04$ & $50 / 50$ & 1.72 & 12.9 & 6.1 & 81 & 0.014 & 0.021 \\
\hline
\end{tabular}

using a pin-on-disc tribometer (CSM Instruments, Switzerland) in accordance to the ISO 7148, ASTM G99-95a and ASTM G133-95 standards to determine the coefficient of friction (COF). Bone pins were used as counterparts against rotating $\mathrm{ZrN}$-coated Ti-6Al$4 \mathrm{~V}$ discs.

When it is impossible to make a ball geometry, e.g. from organic matter of animal origin (bone, cartilage, etc.), the pin-on-disk configuration provided by ${ }^{\circ}$ CSM Instrument tribometer is perfectly adapted for this case (Figure 1). The pin holder is positioned at $45^{\circ}$; this allows to make several tests with one pin. The tribological test parameters are listed in Table 2 .

\subsubsection{Electrochemical analyses}

The electrochemical corrosion tests were carried out using a conventional three-electrode cell of $300 \mathrm{ml}$ capacity and Gamry ${ }^{\circ}$ Potentiostat/Galvanostat Reference 1000. The cell was fitted with a coated Si sample as working electrode (WE), saturated calomel electrode (SCE) as the reference electrode and platinum as a counter electrode (CE). The corrosion behaviour was evaluated by measuring the open circuit potential (OCP) after $3600 \mathrm{~s}$ in $150 \mathrm{ml}$ of $0.9 \% \mathrm{NaCl} \mathrm{PS}$ at room temperature with a scan rate $s=1 \mathrm{mV} / \mathrm{s}$. The corrosion potential $\left(E_{\text {corr }}\right)$ and the corrosion current density $\left(I_{\text {corr }}\right)$ were deduced from the Tafel plot (i.e. $\log i$ vs. $E$ plot). Electrochemical impedance spectroscopy (EIS) tests were conducted in a frequency range from $10^{5}$ to $10^{-2} \mathrm{~Hz}$ at a rate of 5 points/decade, in $E_{\text {ocp }}$ vs. SCE. The potentiodynamic polarization test was raised from -1 to $+1 \mathrm{~V}$, at a scan rate of $1 \mathrm{mV} / \mathrm{s}$. The surface contact of the sample with the electrolyte was $0.5 \mathrm{~cm}^{2}$. EIS parameters were calculated using the ZView software (Scribner Associates, Inc).

\section{Results and discussion}

\subsection{ZrN coatings microstructural characterization}

Figure 2 shows SEM images of an as-deposited $\mathrm{ZrN}$ coating on a $\mathrm{Si}$ substrate. There are some sputtering defects, e.g. pits and droplets, as shown in Figure 2

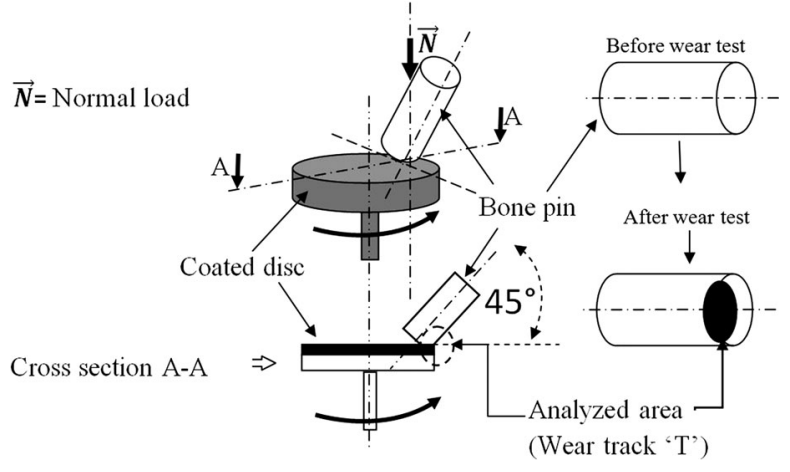

Figure 1. Schematic of the pin-on-disc tests. 
Table 2. Pin-on-disc test conditions.

\begin{tabular}{lc}
\hline Parameters & Value \\
\hline Velocity $(\mathrm{cm} / \mathrm{s})$ & 2 \\
Applied load $(\mathrm{N})$ & 2 \\
Total sliding distance $(\mathrm{m})$ & 5 \\
Wear track diameter $(\mathrm{mm})$ & 4 \\
Environment & Air \\
Temperature $\left({ }^{\circ} \mathrm{C}\right)$ & $20 \pm 3$ \\
Humidity $(\%)$ & $40 \pm 5$ \\
\hline
\end{tabular}

(a-b). All films have an overall thickness of $\sim 1.6$ to $1.9 \mu \mathrm{m}$ and exhibit a columnar structure, as shown in Figure 2(c). The surface roughness of the samples is shown in Table 2. No remarkable differences in roughness parameters $\left(R_{\mathrm{a}}, R_{\mathrm{q}}\right)$ are observed. The $\mathrm{ZrN}-01$ and $\mathrm{ZrN}-02$ samples have a relatively low oxygen content in comparison to $\mathrm{ZrN}-03$ and $\mathrm{ZrN}-04$.

\subsection{Wear behaviour}

\subsubsection{COF of the $\mathrm{ZrN}$ coatings}

Figure 3 shows the friction coefficient curves of the $\mathrm{ZrN}$ films sliding against bovine bone in dry conditions. It shows that the friction coefficients of the four coatings possess similar features, i.e. the friction curves of $\mathrm{ZrN}$ films are characterized by two different stages. The first stage represents run-in and ends with a rapid increase of the COF; the second stage was the steady state wear regime.

During dry sliding tests, the following scenario most probably occurs; at the beginning of the wear test, there is a severe material transfer between the coating and the pins, which leads to an increase of the COF. When the steady state is reached, the material transfer is slowly reduced and stabilized after a large percentage of the wear track area is covered with the transferred material. At the steady state, the highest COF value $(\sim 0.58)$ was observed for the $\mathrm{ZrN}-02$ coating surface, whereas lower COF values $(\sim 0.38)$ were obtained for the other three $\mathrm{ZrN}$ coatings (Figure 3 ). Thus, the COF is fairly high. That is the disadvantage of hard ceramic coatings ( $\mathrm{ZrN})$, e.g. their brittleness and relatively high COF. The COF of the uncoated substrate at the

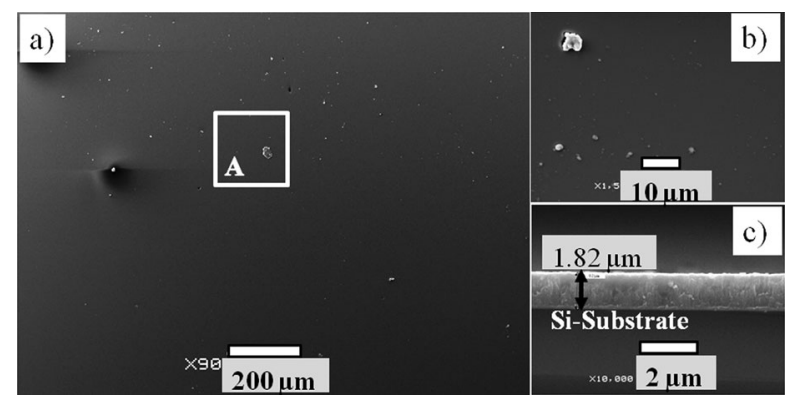

Figure 2. SEM images of the as-deposited $\mathrm{ZrN}-01$ coating on $\mathrm{Si}$ substrate: (a) global view of the surface, (b) magnified image of the region enclosed by the white square (area A) and (c) crosssection image of the same sample.

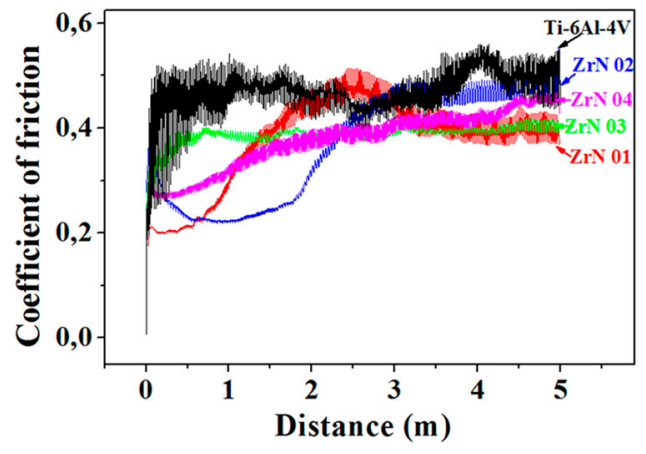

Figure 3. COF of the $\mathrm{ZrN}$ coatings sliding against bone counterparts.

steady state was $\sim 0.58$. From Figure 3 , there is clear evidence that, after $3 \mathrm{~m}$ of sliding distance the coatings are destroyed.

The wear volume loss of the $\mathrm{ZrN}$ coatings/bone couple was not measurable as it was of the order of the surface roughness of the film. In addition, the wear scars on the bone pin could not be estimated because of the low interaction between bone and light in profilometry. So, quantitative data of wear rate were not possible in this study. Only a qualitative analysis of the wear tracks was conducted using SEM/EDS.

\subsubsection{Wear mechanisms of the $\mathrm{ZrN}$-coated discs}

Figure 4 shows the wear tracks of $\mathrm{ZrN}$ coatings on $\mathrm{Ti}$ $6 \mathrm{Al}-4 \mathrm{~V}$ substrates tested against bone pins as counterparts in dry conditions. The primary wear mechanism appears to be abrasion, as shown in Figure 4(a-d). In addition to grooves and scratches parallel to sliding direction, wear debris accumulated in the wear tracks are also observed as deep furrows from trapped particles (Figure 4(c)). The elemental composition of some isolated particles, analysed by EDS, indicates the presence of both bone elements $(\mathrm{Na}, \mathrm{Mg}, \mathrm{Ca}, \mathrm{K}$, etc.) and coating elements ( $\mathrm{Zr}$ and oxygen) in the adhered film (points 1, 2, 3, 4 in Figure 4(a-e)). So, the wear debris is a mixture of the antagonist pair components. From this, one can conclude that bone adhesion to the disc is the second wear mechanism observed in the $\mathrm{ZrN} /$ bone contact pair. SEM analysis also revealed some areas within the wear track where the coating did not appear to be damaged after the wear tests. No plastic deformation was detected in the wear tracks on any of the coatings.

\subsubsection{Wear mechanisms of the bovine bone pins}

Bone is a heterogeneous and anisotropic material. It has a hierarchically organized structure and is often classified as a 'composite material' [6]. At the highest hierarchical level (with feature sizes $\sim 1$ to $5 \mathrm{~mm}$ ), there are two types of bone: cortical bone (which is the type used in this study) and trabecular bone. Cortical bone consists of repeating units called Haversian 

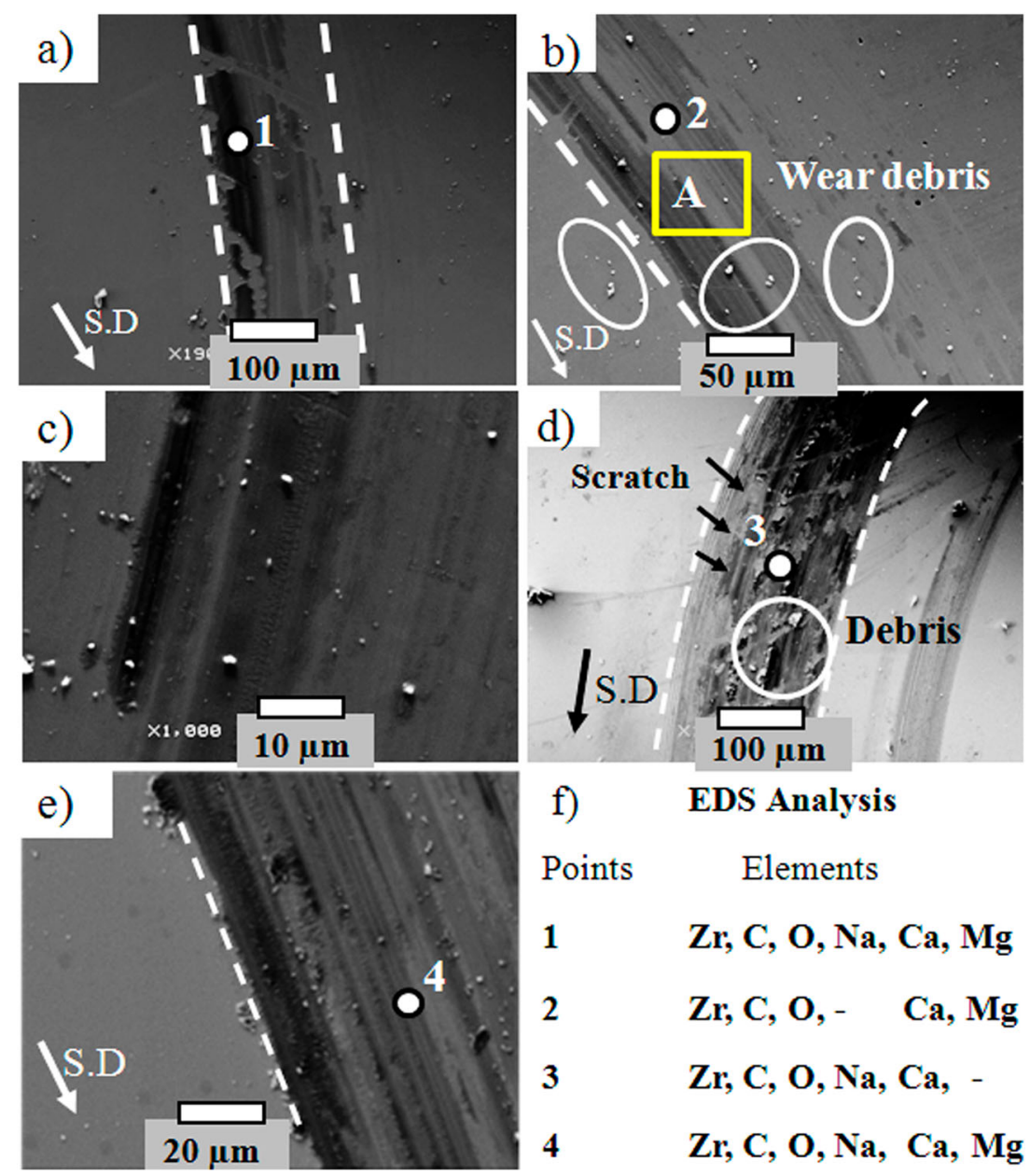

f) EDS Analysis

Points Elements

$1 \mathrm{Zr}, \mathrm{C}, \mathrm{O}, \mathrm{Na}, \mathrm{Ca}, \mathrm{Mg}$

$2 \mathrm{Zr}, \mathrm{C}, \mathrm{O},-\mathrm{Ca}, \mathrm{Mg}$

3

$\mathrm{Zr}, \mathrm{C}, \mathrm{O}, \mathrm{Na}, \mathrm{Ca},-$

$\mathrm{Zr}, \mathrm{C}, \mathrm{O}, \mathrm{Na}, \mathrm{Ca}, \mathrm{Mg}$

Figure 4. Wear mechanism of ZrN coatings: abrasion (scratches-grooves) and bone adhesion wear; (a) wear track of ZrN-01, (b) wear track of ZrN-02, (c) zoom of the square A, (d) wear track of ZrN-03, (e) wear track of ZrN-04 and (f) EDS analysis results at points 1, 2, 3,4 ; (S.D - sliding direction).

systems or osteons. [6]. The macrostructure of the bone pin specimen (cortical bone) is shown in Figure 5.

Figure $6(a-d)$ shows micrographs of the bone pin wear scars. It appears that the edges of the bone pin (see Figure 1; analyzed area (Wear track ' $T$ ')) become larger after acting as counterparts against $\mathrm{ZrN}$-coated discs. Wear scars also reveal deformation of the Haversian system, lacunae (crevasses indicated by white narrows), isolated wear particles (black narrows) and entrapped particles (ellipse). EDS analyses, carried out at different locations (isolated as well as entrapped particles) within the wear scars, indicate that a mixture of both the antagonist elements in contact was found. Abrasive wear is the only wear mechanism observed on the bone pins.

When sliding against $\mathrm{ZrN}$-coated discs, segments of the bone pins were initially scraped off by surface asperities along the wear track. This is due to the large difference in mechanical properties between the antagonists in contact. A literature study reveals the average hardness $(H)$ and elastic modulus $(E)$ of cortical bovine bone obtained from nanoindentation in
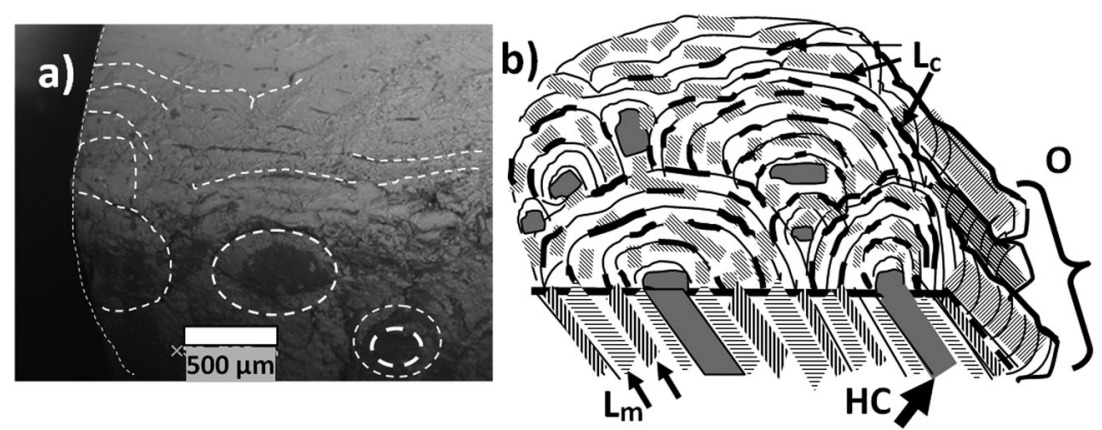

Figure 5. (a) SEM micrograph of a bone pin specimen. (b) A schematic diagram illustrating the macrostructure of cortical bone; $\mathrm{O}$ Osteons (Haversian systems), $L_{m}$ - concentric lamellae, HC - Haversian canal and $L_{C}-$ lacunae. 


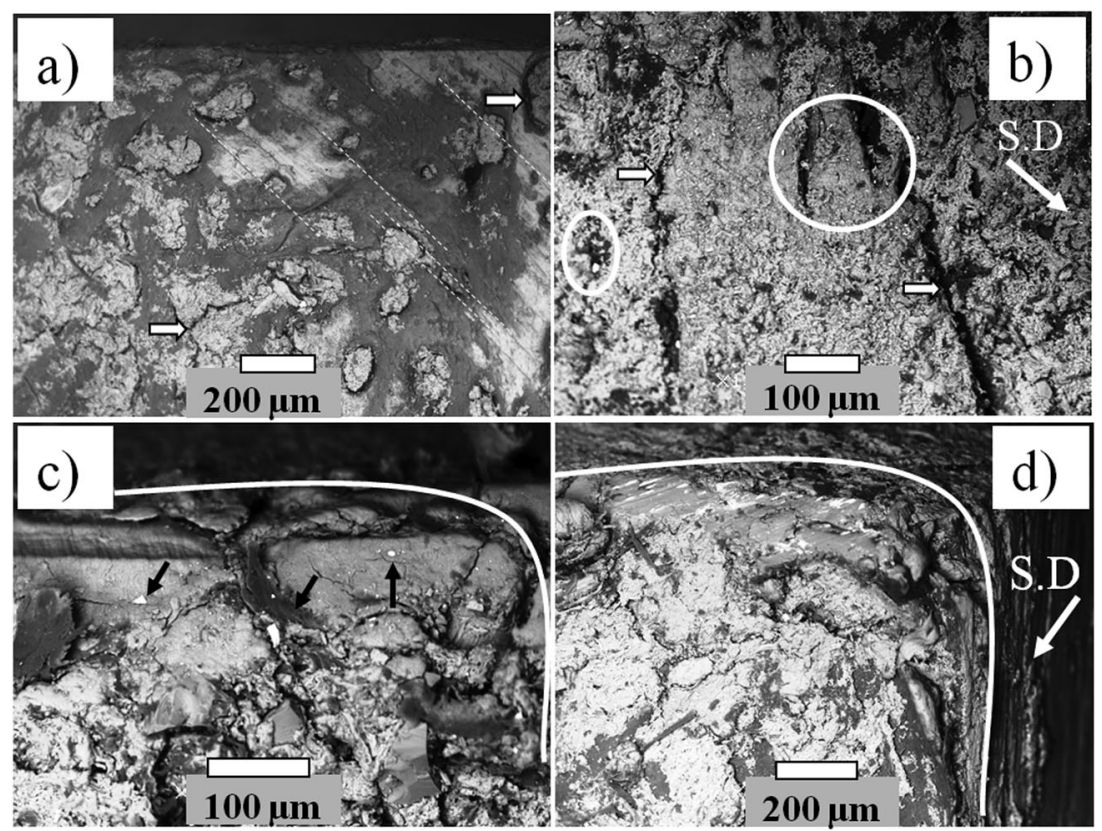

Figure 6. SEM images of wear scars of bone pins after pin-on-disc tests for: (a) ZrN-01, (b) ZrN-02, (c) ZrN-03 and (d) ZrN-04 (dash lines indicate scratch marks, SD - sliding direction).

transversal direction between 0.647 and $0.892 \mathrm{GPa}$ and 19.8 $\pm 1.6 \mathrm{GPa}$, respectively [7]. $\mathrm{ZrN}$ coatings hardness and modulus values range from 15 to $34 \mathrm{GPa}$ and 240 to $320 \mathrm{GPa}$, respectively [8]. As the number of sliding cycles increases, the transferred layer onto $\mathrm{ZrN}$ surface becomes brittle and is destroyed through fatigue; the resulting wear debris acts as a third body.

\subsection{Electrochemical behaviour}

\subsubsection{Potentiodynamic polarization measurements}

Figure 7 (a) shows the potentiodynamic polarization curves (plots of potential vs. log current density) of the $\mathrm{ZrN}$ coatings exposed to the PS for $2 \mathrm{~h}$. All specimens form an anodic domain (labelled ' 1 '), which corresponds to the formation of a self-passivating $(\mathrm{Zr}, \mathrm{N}$,

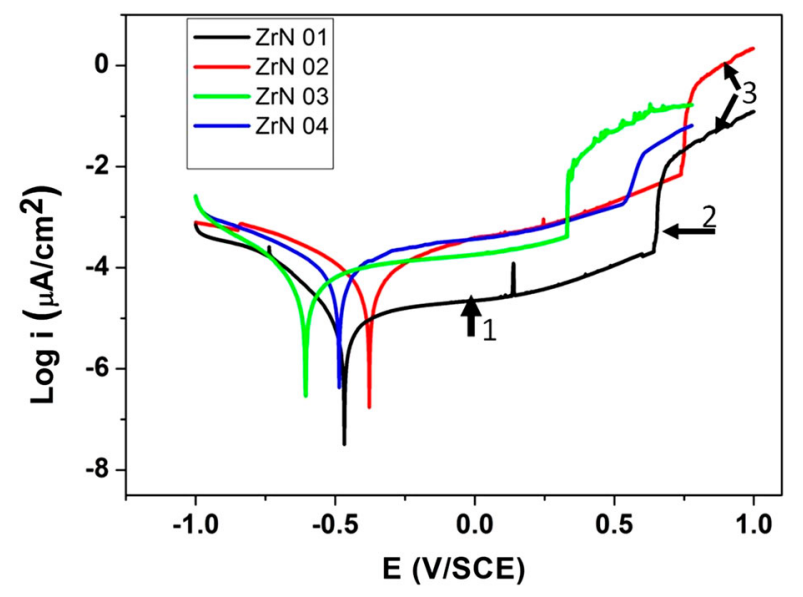

Figure 7. Potentiodynamic polarization curves of ZrN coatings in physiological liquid solution.
O) film after being soaked for a period of time. The size of this domain is indicative of the durability of the selfpassivating film and the corrosion resistance of each coating. For example, the anodic plateau remained flat from -0.4 up to $+0.65 \mathrm{~V}$ in the case of $\mathrm{ZrN}-01$. The rupture of the passive film occurs in the trans-passivation domain (labelled '2'). In this domain, the current density abruptly increases as the materials start to corrode (labelled ' 3 '). The polarization resistance $\left(R_{\mathrm{p}}\right)$ of Tafel curves, which takes into consideration both the corrosion current density and the slopes of polarization curves, can provide a quantitative ranking of coatings resistance to corrosion and can be estimated using the well-known Stern-Geary equation.

Table 3 summarizes the relevant values from the Tafel plots. From these results, it is clear that $\mathrm{ZrN}-01$ is significantly more corrosion-resistant (high value of $R_{\mathrm{p}}$ and low value of $I_{\text {corr }}$ ) when compared to the other three coatings.

\subsubsection{EIS analysis}

Each sample's impedance was measured after $1 \mathrm{~h}$ of immersion in the PS. Nyquist plots of the real and imaginary parts of the impedance are shown in Figure 8(a). The plots show that all tested samples are characterized by two capacitive loops in the high and medium

Table 3. Potentiodynamic polarization test results.

\begin{tabular}{lcccccr}
\hline Samples & $\begin{array}{c}E_{\text {corr }} \\
(\mathrm{mV})\end{array}$ & $\begin{array}{c}I_{\text {corr }} \\
(\mu \mathrm{A} / \\
\left.\mathrm{cm}^{2}\right)\end{array}$ & $\begin{array}{c}a(\mathrm{mV} / \\
\mathrm{dec})\end{array}$ & $\begin{array}{c}c(\mathrm{mV} / \\
\mathrm{dec})\end{array}$ & $\begin{array}{c}R_{\mathrm{p}} \\
(\Omega)\end{array}$ & $x^{2} .10^{-4}$ \\
\hline ZrN-01 & -466.76 & 0.007 & 174.8 & 544.3 & $8.04 .10^{6}$ & 15.99 \\
ZrN-02 & -376.53 & 0.042 & 297.7 & 274.5 & $1.47 .10^{6}$ & 13.42 \\
ZrN-03 & -612.98 & 0.037 & 512.7 & 220.2 & $1.80 .10^{6}$ & 14.44 \\
ZrN-04 & -486.20 & 0.044 & 202.4 & 219.9 & $1.04 .10^{6}$ & 9.10 \\
\hline
\end{tabular}



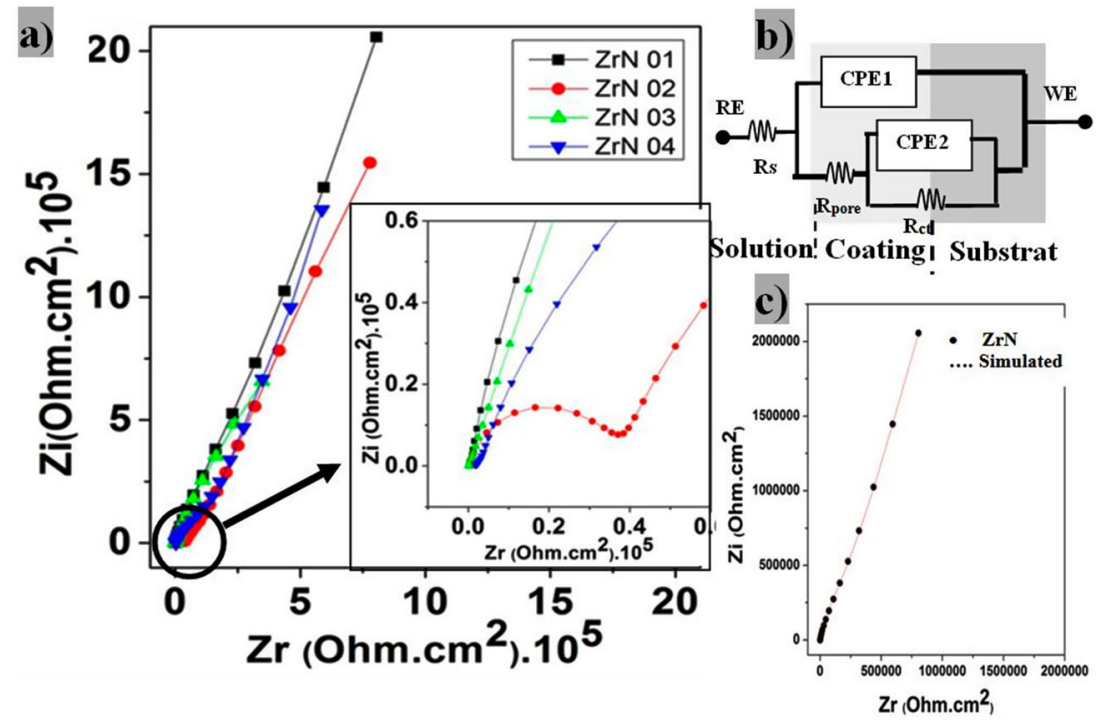

Figure 8. Electrochemical test results (EIS): (a) Nyquist plots of tested specimen in physiological liquid solution, (b) equivalent circuit model and (c) example of fitting curve (WE = working electrode and $\mathrm{RE}=$ reference electrode).

frequency range. By comparing the diameters of the loops in the Nyquist plot, the sample's corrosion properties can be easily evaluated. Larger diameter loops equate to higher corrosion resistance. This analysis supports the previous conclusion: $\mathrm{ZrN}-01$ has the best corrosion resistance of the four tested samples. An equivalent circuit (EC) model, which is shown in Figure 8(b), was selected for quantitative studies. This EC is extensively used in similar situations [9]. Figure 8(c) shows good agreement between the experimental and modelled values. The fitted line was plotted as a dashed line. The fitting errors for each configuration in this study were less than $9 \%$.

In the selected equivalent circuit, $R_{\mathrm{S}}$ represents the electrolyte resistance. The Constant Phase Elements, CPE1 and CPE2, are the double layer capacitance and the coating capacitance respectively. $R_{\mathrm{ct}}$ is the charge transfer resistance and $R_{\text {pore }}$ represents the pore resistance (and other fails of coating).

The overall corrosion resistance of the coating can be estimated by the sum of all resistances of the circuit model in accordance with the method described by Subramanian et al. [9]. Therefore, using the quantitative data given in Table 4, the $\mathrm{ZrN}-01$ coating presents the highest resistance against corrosion in a physiological liquid solution of the four tested samples, as expected.

\subsection{Biocompatibility}

The bactericidal properties of $\mathrm{ZrN}$ coatings were assessed using $S$. aureus bacteria. This bacterium is the main pathogenic microbe responsible for implant associated infections [10]. Two kinds of samples are used: $\mathrm{ZrN}$ coating on silicon wafer and an uncoated Ti-6Al-4V substrate. Ti6-Al-4V is one of the most studied biomaterials, and its biocompatibility in various environments has been well documented. This sample acts as a 'reference' material for the comparison of the biocidal properties of $\mathrm{ZrN}$ coatings.

Following sterilization in an autoclave, three samples (bare Ti-6Al-4V, $\mathrm{ZrN}-01 / \mathrm{Si}$ and $\mathrm{ZrN}-03 / \mathrm{Si}$ ) were exposed to bacteria suspended in a buffered glucose broth and incubated at $37^{\circ} \mathrm{C}$ for $24 \mathrm{~h}$. To quantitatively assess the antibacterial effect of the three samples, the plate count method, in association with the dilution method, is used [11]. Specimen A is the liquid solution collected from the suspension which contained the metallic Ti-6Al-4V substrate. Specimen $\mathrm{B}$ and specimen $\mathrm{C}$ are the liquid solutions which previously contained the $\mathrm{ZrN}-01 / \mathrm{Si}$ and $\mathrm{ZrN}-03 / \mathrm{Si}$ samples, respectively. Twenty microlitres of each specimen are spread over a sterilized Petri dish coated with mannitol salt agar, also known as Chapman medium. The coated Petri dishes were incubated at $37^{\circ} \mathrm{C}$ for $24 \mathrm{~h}$. Quantitative test results (counts) are given in term of colony forming units per millilitre (CFU/ml).

After incubation, the $S$. aureus colonies are clearly visible (Figure 9) and were easily counted. The results indicate that $S$. aureus bacteria were completely killed in specimen $B$, while the surviving bacterial colonies are $3.2 \times 10^{5}(\mathrm{CFU} / \mathrm{ml})$ for specimen $\mathrm{A}$ and $5.2 \times 10^{5}$ (CFU/ml) for specimen C. Specimen B and Specimen $\mathrm{C}$ have approximately similar surface parameters (i.e. roughness, morphology, etc.) but there is a noticeable difference in the oxygen content of the samples. So, surface morphology effects cannot explain the difference in the biocidal effect of these two specimens (B and $C$ ). In addition, it has been reported that a surface roughness $<0.2 \mu \mathrm{m}$ may not affect bacterial adhesion because most bacteria are $>0.2 \mu \mathrm{m}$ [12]. 
Table 4. EIS data obtained by equivalent circuit simulation.

\begin{tabular}{|c|c|c|c|c|c|c|c|}
\hline Samples & $\begin{array}{c}R_{\mathrm{s}} \\
\left(\Omega \mathrm{cm}^{2}\right)\end{array}$ & $\begin{array}{c}\text { CPE1 } \\
\left(\mu \mathrm{F} / \mathrm{cm}^{2}\right)\end{array}$ & $a_{1}$ & $\begin{array}{c}R_{\text {pore }} \\
\left(\Omega \mathrm{cm}^{2}\right)\end{array}$ & $\begin{array}{c}\text { CPE2 } \\
\left(\mu \mathrm{F} / \mathrm{cm}^{2}\right)\end{array}$ & $a_{2}$ & $\begin{array}{c}R_{\mathrm{ct}} \\
\left(\Omega \mathrm{cm}^{2}\right)\end{array}$ \\
\hline ZrN-01 & 163.1 & $2.6810^{-6}$ & 0.91 & $67510^{3}$ & $2.0810^{-6}$ & 0.73 & $20510^{6}$ \\
\hline $\mathrm{ZrN}-02$ & 155.3 & $16.2310^{-9}$ & 0.86 & $35.710^{3}$ & $3.9210^{-6}$ & 0.74 & $31.0810^{6}$ \\
\hline ZrN-03 & 304.3 & $5.1110^{-6}$ & 0.96 & $4.610^{3}$ & $5.8510^{-6}$ & 0.72 & $13.3910^{6}$ \\
\hline ZrN-04 & 365.2 & $2.4610^{-6}$ & 0.78 & $362.910^{3}$ & $3.9210^{-6}$ & 0.81 & $48.8510^{6}$ \\
\hline
\end{tabular}
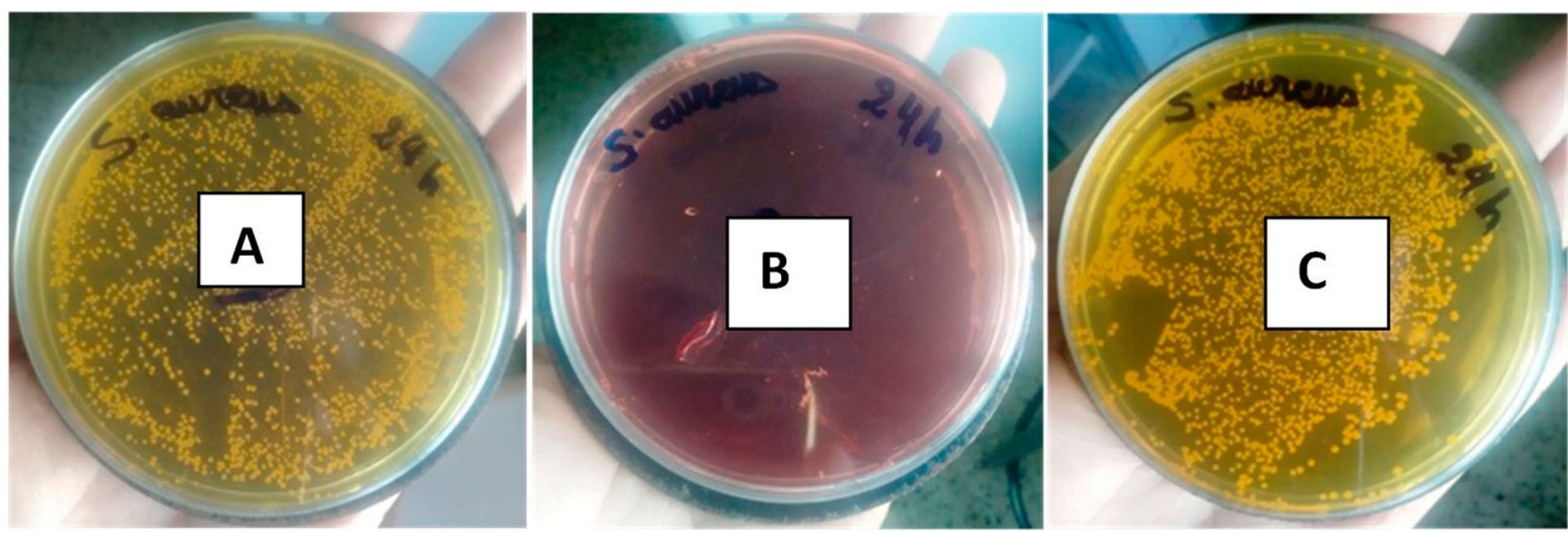

Figure 9. Staphylococcus aureus colonies grown in sterilized Petri dishes of: (a) specimen A, (b) specimen B and (c) specimen C.

However, chemical interactions between microorganisms and biomaterial surfaces can have a significant effect on bioadhesion and the proliferation process $[13,14]$. Within liquids, oxide surfaces can be positively charged and bacteria typically are negatively charged [15]. Consequently, bioadhesion of bacteria is significantly enhanced in the presence of surface oxides. This result is in accordance with conclusions reported by Vadillo-Rodriguez et al. [14]. The presence of oxygen, and the development of surface oxides, can also affect the release of $\mathrm{Zr}$ ions. Zirconium ions interact with the bacterial cell wall, which may disturb its permeability and/or may inhibit bacterial metabolism [13].

Therefore, oxygen content appears to be a key limiting factor in the biocompatibility of $\mathrm{ZrN}$ surfaces. Oxygen content leads to higher bioadhesion aptitude and more colonies (proliferation). As a result, there is a higher probability of $S$. aureus survival and increased chances for infection.

\section{Conclusion}

From the above-mentioned results, it can be concluded that:

(i) All coatings exhibited good wear properties against bone counterparts. The primary wear mechanisms were abrasive wear and bone adhesion for the $\mathrm{ZrN}$-coated discs and thirdbody abrasive wear for the bone counterparts.

(ii) All coatings exhibited good corrosion resistance. However, the oxygen content seems to play a more significant role here than in the wear tests. The sample with the lowest oxygen content,
ZrN-01 $\left(\mathrm{O}_{2}=1.5\right.$ wt. \%), showed the highest corrosion resistance in both potentiodynamic testing and EIS.

(iii) Bioactivity of an uncoated Ti-6A-14V disc substrate and the $\mathrm{ZrN}-03\left(\mathrm{O}_{2}=4.9 \mathrm{Wt}\right.$. \%) coating shows a poor antimicrobial effect against the $S$. aureus bacteria. A strong biocide effect was observed with the surface of $\mathrm{ZrN}-01 \quad\left(\mathrm{O}_{2}=1.5\right.$ Wt. \%) coating; no microbes were observed after $24 \mathrm{~h}$ of contact time.

\section{Acknowledgements}

The authors are thankful to Mr. Denis LAGADRILLERE for SEM/EDS analysis.

\section{Disclosure statement}

No potential conflict of interest was reported by the authors.

\section{ORCID}

C. Ramoul (1) http://orcid.org/0000-0002-6794-7704

C. Nouveau (1) http://orcid.org/0000-0002-5552-2020

\section{References}

[1] Dearnley P. A Introduction to surface engineering. New York: Cambridge University Press; 2017, p. 449-480.

[2] Calderon SV, Ferreri I, Henriques M, et al. Nano-galvanic coupling for enhanced $\mathrm{Ag}^{+}$release in $\mathrm{ZrCN}-\mathrm{Ag}$ films: antibacterial application. Surf Coat Technol. 2016;298:1-6. 
[3] Grischke J, Eberhard J, Stiesch M. Antimicrobial dental implant functionalization strategies - a systematic review. Dent Mater J. 2016;35(4):545-558.

[4] Menghani J, Pai KB, Totlani MK. Corrosion and wear behaviour of $\mathrm{ZrN}$ thin films tribology. Mater Surf Interfaces. 2013;5:122-128.

[5] Ningshen S, Gupta RK, Kamal S, et al. Corrosion study of $\mathrm{ZrN}$ deposited on 304L stainless steel. Surf Eng. 2013;29:264-270.

[6] Grimm MJ. Orthopedic biomaterials. In: Kutz M, editor. Standard handbook for biomedical engineering and design 2nd ed. New York: McGraw-Hill.; 2004. p. 15.1-15.22.

[7] Wang XJ, Li YC, Hodgson PD, et al. Nano- and macroscale characterization of the mechanical properties of bovine bone. Mater Sci Forum. 2007;31:156-159.

[8] Dorcioman G, Craciun D, Lambers E, et al. Wear tests of $\mathrm{ZrC}$ and $\mathrm{ZrN}$ thin films grown by pulsed laser deposition. Appl Surf Sci. 2014;306:33-36.

[9] Subramanian B, Swaminathan V, Jayachandran M. Microstructural, tribological and electrochemical corrosion studies on reactive DC magnetron sputtered
Zirconium nitride films with $\mathrm{Zr}$ interlayer on steel. Met Mater Int. 2012;18(6):957-964.

[10] Lauderdale KJ, Malone CL, Boles BR, et al. Biofilm dispersal of community-associated methicillin-resistant Staphylococcus aureus on orthopedic implant material. J Orthop Res. 2010;28:55-61.

[11] Merck Microbiology Manual 12th Edition. (2005). Merck KGa A 64271 Darmstadt, Germany. Available from: https://www.scribd.com/doc/94454909/MerckMicrobiology-Manual-12th.

[12] Ji MK, Park SW, Lee K, et al. Evaluation of antibacterial activity and osteoblast-like cell viability of TiN, $\mathrm{ZrN}$ and (Til-xZrx)N coating on titanium. J Adv Prosthodont. 2015;7:166-171.

[13] Manuel L, Palacio B, Bhushan B. Bioadhesion - a review of concepts and applications. Phil Trans R Soc A. 2012;370:2321-2347.

[14] Vadillo-Rodriguez V, Logan BE. Localized attraction correlates with bacterial adhesion to glass and metal oxide substrate. Environ Sci Technol. 2006;40:2983-2988.

[15] Bixer GD, Bhushan B. Biofouling: lessons from nature. Phil Trans R Soc A. 2012;370:2381-2417. 